\title{
Theoretical and Experimental Determination of a Velocity Profile under Turbulent Air Flow in Pipework
}

\section{Mária Čarnogurská ${ }^{1}$, Miroslav Př́íhoda², Marián Lázár ${ }^{1}$}

${ }^{1}$ Department of Power Engineering, Faculty of Mechanical Engineering, Technical University of Košice, Vysokoškolská 4, 04200 Košice, Slovak Republic. E-mail: maria.carnogurska@tuke.sk, marian.lazar@tuke.sk

${ }^{2}$ Department of Thermal Engineering, Faculty of Metallurgy and Materials Engineering, VŠB - Technical University of Ostrava, 17. listopadu 15, 70833 Ostrava-Poruba, Czech Republic. E-mail: miroslav.prihoda@ vsb.cz

The paper experimentally and theoretically analyses the velocity profile of air in laboratory stand pipework. Flow velocities measured using a hot-wire anemometer and a vane anemometer were compared with the results of numerical simulation. The $k-\varepsilon$ turbulence model was used in the numerical solution of flow rates and for determining the velocity profile using the ANSYS_CFX program. Using power law, this profile was described via an analytical function. Velocities determined by measuring with both instruments in the investigated place in the pipework showed lower values in comparison with the numerical solution. The cause of the difference in velocities was probably inaccurate stating of the volume flow of air through the ultrasonic anemometer. Measurements and simulation showed slight asymmetry in velocity which is related to an insufficiently large volume of the equalisation chamber and the mutual position of the input and output openings.

Keywords: Velocity profile, Hot-wire anemometer, Vane anemometer, Numerical simulation

\section{Acknowledgement}

The paper was prepared with the support of the VEGA 1/0004/2014 ME SR and SP2015/86-FMMI VŠB TUO.

\section{References}

[1] ČARNOGURSKÁ, M., PŘÍHODA, M., LÁZÁR, M., JURKO, P. (2015). Analýza rýchlostného pol’a prúdu vzduchu v potrubí laboratórneho stendu. In: Proceedings of Extended Abstracts of $34^{\text {th }}$ Conference of Departments of Fluids Mechanics and Thermomechanics, pp. 13 - 14. UJEP, Ústí nad Labem.

[2] JÖRGENSEN, F. (2002). How to measure turbulence with hot-wire anemometers: a practical guide. [elektronická verzia]. Denmark: Dostupné na: 〈http://www.dantecdynamics.com/how-to-measure-turbulence-practical-guide>

[3] KUNDYS, J., FABIÁN, P., KOZUBKOVÁ, M. (2004). Měření žárovým anemometrem, Anemometr MiniCTA, s. 5 - 17. VŠB - TUO, Ostrava.

[4] JANALÍK, J. (2006). Měrení turbulentních fluktuací rychlosti, s. 16 - 21. VŠB - TUO, Ostrava.

[5] RÉDR, M., PŘíHODA, M. (1991). Základy tepelné techniky, s. 311 - 314. SNTL, Praha.

[6] JANDAČKA, J., PAPUČÍK, Š., DEKÝŠ, V., MELICHER, R. (2008). An analysis of fair flow at various spacing of fans on a physical model of a road tunnel. Communications, Vol. 10, No. 3, pp. 40 - 44. TU of Žilina, Slovakia.

[7] JASMINSKÁ, N., BRESTOVIČ, T., PUŠKÁR, M. (2014). Analytical and numerical proposal for designing plastic vessels. Applied Mechanics and Materials, Vol. 611, pp. 227-238. Scientific.Net, Switzerland.

[8] SKOČILASOVÁ, B., SOUKUP, J. (2013). Simulation of Liquid Flow in Pipe. Manufacturing Technology, Vol. 13, No. 4, pp. 542 - 547. UJEP, Ústí nad Labem.

[9] CHALUPA, M., VEVERKA, J., VLACH, R. (2014). Usage of Track Link Dynamic Motion Simulation. Manufacturing Technology. Vol. 14, No. 4, pp. 545 - 554. UJEP, Ústí nad Labem.

[10]PŘÍHODA, M., MOLÍNEK, J., PYSZKO, R., VELIČKA, M., VACULÍK, M., BURDA, J. (2009). Heat transfer during cooling of hot surfaces by water nozzles. Metallurgy. Vol. 48, No. 4, pp. 235 - 238. Croatian Metallurgical Society, Croatia. 